Sacred Estrangement 
This page intentionally left blank. 


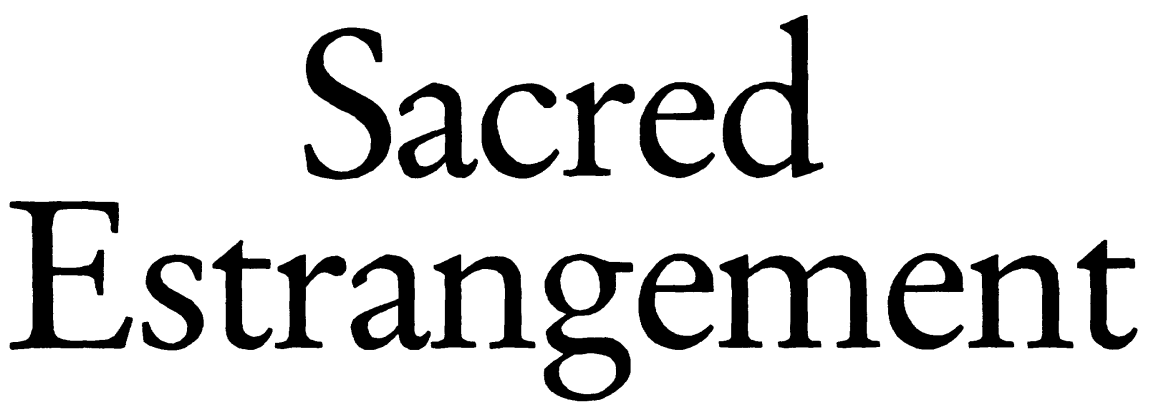

\section{The Rhetoric of Conversion} in Modern American Autobiography

\section{Peter A. Dorsey}

THE PENNSYLVANIA STATE UNIVERSITY PRESS

University Park, Pennsylvania 
Library of Congress Cataloging-in-Publication Data

Dorsey, Peter A., 1958-

Sacred estrangement : the rhetoric of conversion in modern American autobiography / Peter A. Dorsey.

p. $\mathrm{cm}$.

Includes bibliographical references and index.

ISBN 0-271-00902-0 (alk. paper)

1. American prose literature-History and criticism. 2. Authors, American-Biography-History and criticism. 3. Christianity and literature-United States. 4. Conversion in literature.

5. Autobiography. I. Title.

PS366.A88D67 1993

$810.9^{\prime} 382-\mathrm{dc} 20$

$92-16589$

CIP

Copyright (C) 1993 The Pennsylvania State University

All rights reserved

Printed in the United States of America

Published by The Pennsylvania State University Press,

Suite C, Barbara Building, University Park, PA 16802-1003

It is the policy of The Pennsylvania State University Press to use acid-free paper for the first printing of all clothbound books. Publications on uncoated stock satisfy the minimum requirements of American National Standard for Information SciencesPermanence of Paper for Printed Library Materials, ANSI Z39.48-1984. 
To my parents

David A. and Maryellen Clarke Dorsey and to Sheila 
This page intentionally left blank. 